\title{
Study on Optimization of Social P.E Major Course System at University
}

\author{
Qi Shenghua, Yue Hong \\ P.E.Teaching Unit, University of Jinan, \\ Shandong 250022, China
}

\begin{abstract}
It uses literature material method, analyzes the theoretical basis of course system optimization and proposes the basis idea of course system reform. The result shows that optimization of social P.E major course system can be conducted through two aspects and three levels, which not only should reflect course structure and type optimization, but also should reflect course content optimization. The course setting should actively adapt to social de velopment and reform demand and actively face society and market, in order to cultivate the talents adapting to social P.E development demand.
\end{abstract}

Keywords: university; social P.E major; course system; optimization;

\section{Introduction}

In recent years, various P.E colleges widely open the channels and cultivate social P.E talents in order to cater to the needs of society. But currently, how is the course setting situation of social P.E major? How to improve the cultivation quality of social P.E talents? For more than a decade, social P.E workers have been discussing these problems, especially the social P.E workers in P.E colleges. Through the investigation of previous graduates of social P.E major in Jinan University, a lthough some graduates are engaged in the work of P.E club, fitness club and various P.E training centers, but few people are engaged in social P.E work. And the employment situation of social P.E major is not optimistic. The main reas on of this situation is that, in current practitioners, most people lack of necessary professional learning or professional education, and the theory knowledge is in shortage. Especially for the demands of different groups of people, it is inadequate in fitness sports guidance as pect[2]. Facing the contradiction of social development new trend and professional talent demand and social P.E majors' employment difficulty, how to do well the social P.E major construction and cultivate social P.E major talents with high level is to be further studied for the social P.E major talent course system.

\section{Status of Current Social P.E Major Course System Construction}

The setting of social P.E major course system is affected by Chinese traditional "more common points and less personality, more theory and less practice" education concept and the former Soviet Union higher education course "department and subject segmentation, meticulous majors". It still has many problems and defects, which mainly reflects in:

\section{(1) Not Outstanding Professional Feature of Course Setting}

Through the analysis of national P.E colleges and normal P.E college teaching plans, we can find that various professional course cultivation targets, courses and various types of course content and teaching material selection have too much in common and less outstanding in professional feature.

\section{(2) Course Structure Flexibility Is Not Enough, Lacking} of Independent Choice.

The current P.E course reform, especially the social P.E course reform, focuses on course types and teaching content, without course structure system optimization reform. Students' professional learning focus is not prominent, without clear choice. The course structure lacks of the corresponding flexibility, limiting students' independent choice.

\section{(3)Course Content Is Old and Repeated.}

At present, social P.E course content teaching is not only to meet the single professional demand to choose teaching content, causing students' single knowledge structure and narrow knowledge aspect, which can not meet the demands of social P.E talent knowledge, high quality and strong ability.

\section{Social P.E Major Course System Optimization}

\section{(1) Theoretical Basis of Course System Optimization}

Course system is the core content of constructing talent cultivation plan, and the scientific and rational course system has decisive significance of realizing talent cultivation target for higher education and high quality [4]. In general, the course system reform includes three levels: 1 . Macro professional setting relates with higher education subject and major setting. 2. Middle course system reform relates with internal course system optimization of a certain major. 3.Micro teaching material system optimization[5]. This study mainly summarizes and concludes the theory and method of medium course system optimization. Medium course system optimization is conducted from three aspects: one is course system structure optimization, two is course type optimization and three is course content optimization.

Course system optimization principles include: 1. 
Foundation. 2. Comprehension. 3. Diversity. 4. Development. 5. Dynamics. 6. Science.

\section{(2) Basis Idea of Social P.E Major Course System Reform}

\section{1)Focusing on Cultivation Plan Revise Work}

1.Strengthening basic course; cultivating students' good character, humanity quality and modern scientific knowledge quality. 2. Prominent professional main course (core course) and professional feature course. 3. Expanding Optional Course; expanding optional course proportion and opening comprehensive course, in order to cultivate talents with strong adaptation ability. Interdisciplinary courses and edge crossing course can make students expand knowledge fields according to their own interest and specialty. 4.Strengthening practice course. The practice course should go through the whole teaching process, and practice course is put into professional course construction[6].

\section{2)Exploring Local Feature Course System}

In the process of running a school, exploring a set of Jinnan feature course system is very necessary. Local feature course system can make full use of colleges' local natural and social resources, which will promote the healthy development of social P.E major.

\section{3)Exploring Shuttle Course System}

It lets students use theory knowledge in practice and find the shortcoming of theory knowledge, then they come back to classroom to study theory knowledge again. Thus, they go through the practice and classroom, and they can constantly enrich the theory knowledge and improve practice ability. They can constantly improve students' theory knowledge and enthusiasm, feeling the achievement of using theory knowledge in practice, in order to constantly improve education teaching quality and take efforts to expand employment field.

\section{(3)Course System Structure Optimization}

Professional course system reform is the focus of college course system reform research, which is one of the main paths of improving education quality[5]. Social P.E major should focus on reflecting P.E science, social science and management science unity and comprehensive angle to think about course system reform problems, and balance the development skills and theory teaching. They focus on skills and theory teaching, which is not consistent with the direction of higher education teaching as the basic education service.

Jinna University social P.E major course structure mode has four aspects of features: one is systematic comprehensive knowledge structure. Two, reflecting theory contacting with practice. Three, common education platform sets humanity social science base module. Four, professional plate platform constructs entertainment and leisure module, P.E industrial operation management module and public fitness module.

\section{(4)Course Type Optimization}

\section{1) Professional Basis Course Should be Wide and Solid.}

Professional base refers to the basic theory, basic knowledge and basic skills of a certain major. In course structure, professional basic courses are divided into two levels, namely, professional skill basic course and professional theory basic course[7]. The basic course of social P.E major should be wide and solid. Wide mainly refers to the course feature of P.E subject. Solid mainly refers to that professional basis course should surround professional talent cultivation target, reflecting professional core basic course, in order to lay a solid foundation for professional learning.

\section{2)Professional Course Should Be Refined and Practical.}

In the process of setting, it should follow the main courses regulated by education department: social P.E introduction, social P.E management, fitness introduction, Chinese P.E health and public fitness entertainment project theory and methods, and we should do it according to talent cultivation demand, in order to lay foundation for professional plate course, namely, leading course.

\section{3)Professional Plate Course Should Be Flexible.}

Professional plate course is students' professional optional plate, and in the direction module design, it should consider the environment background of current social development, and the students' individual feature and interest, making students can choose their own professional development direction according to social demand their own interest and willingness in the third year. Also, professional direction should conform to social de mand and feature, for specialty education. For Jinan University, professional plate platform can set three plates from le isure entertainment, P.E industry operation management and public fitness.

\section{(5)Course Content Optimization}

Course content reform and optimization have been the main research focus of higher education teaching reform. Course system can conduct overall optimization, and to a large extent, it depends on course content selection, especially the course content re-organization, integration and selection and concise[4]Three levels of course content setting should surround talent cultivation target, and the course horizontal and vertical logic relationship can cut selectively.

\section{Social P.E Major Course Construction Countermeasures}

\section{(1)Improving Practice Class Hour Proportion}

According to our previous survey result, many clubs need social P.E students to practice and work there. Clubs can alleviate the contradiction between the staff shortage, and for students, it is a good learning opportunity. Through the win-win cooperation form, it can fully solve the funding problem. 


\section{(2)Subject and Course Adjustment}

First, it should strengthen the horizontal relation between social P.E major course and relevant subjects, deleting some old courses with old teaching content, increasing some courses of reflecting social P.E work new direction and social demand. For content repetition course, it can delete or set it again.

\section{(3) Expanding Employment Direction}

Currently, in social P.E major cultivation plan, it has a fuzzy definition of graduate employment in this direction, which is not good for course system construction. Some course setting is seemingly related with employment direction, in fact it is very different. On the other hand, clear employment direction can make students' learning more objective.

\section{(4) Teacher Cultivation and Introduction}

We are try ing the training method of similar majors of teachers for short-term or long-term practice. Or we can directly introduce high level teachers from other professional colleges, also in strengthening teacher team strength, it should increase some large market demand courses. It not only has positive role in improving graduates' employment rate, but also it conforms to our university's "improving operation connotation" goal.

Course system optimization should not only reflect course structure and type optimization, but also reflect course content optimization. Course structure and type optimization has a clear direction for talent cultivation, which is material level optimization, but the course content optimization provides rich spiritual food for talent cultivation, which is spiritual level optimization. The two optimizations can ensure cultivating high-quality professional talents.

\section{Acknowledgments}

Jinan University Teaching Research Project: P.E major course system and teaching content overall optimization research $(\mathrm{JZ1223})$

\section{References}

[1] Yang Yehong. Study on Chaohu College social P.E major course system[J]Journal of Chaohu College ，2012，14 (3): 147-151

[2] Ye Guanghua, Dong Jun. Social P.E major course system optimization system method and construction. An'hui P.E Science and Technology, 2006, 27 (4): 67-70

[3] Shu Yunjiu, Tao Ye. Study on university social P.E major course system[J]Journal of Shandong P.E College ，2006, 22 (5): 101-103

[4] Zeng Dongmei. Course system optimizat ion of three levels[J]. Higher Science Education, 2003, (2): 34-38

[5] Sun Gengnian. Course system optimization system view and system method[J]Higher Education Research, 2001， (2): 86-90

[6] Jia Zhengrong, Wang Ying, Ji Jlawen. Study on higher Norma Universities reform of socialP.E major course system[J]. Milit ary P.E College Journal, 2011，30（3): 103-103
[7] Li Zhengrong. Study on Wuhan P.E College social P.E major course system[J]Wuhan P.E College Journal, 2006，40（3): 103-105 